\title{
Discount Retail Profitability: A HARBINGER FOR E-COMMERCE?
}

\author{
Richard Skolnik \\ State University of New York at Oswego \\ Oswego, NY
}

\begin{abstract}
Expansion of electronic commerce has the potential to increase retail productivity. However, these gains may not translate into enhanced retailer profitability. This study examines profitability of the discount retail industry from 19811998, a period during which the industry realized significant productivity gains. Although productivity measures like inventory turnover and sales per employee increased during this period, industry profitability did not increase. Instead, consumers benefited from the increased efficiency through paying lower markups. The experience of the discount retail industry may indicate that retailers face a product price treadmill: gains in efficiency result in lower prices rather than higher profits. The projected efficiencies of the Internet and the expansion of electronic commerce may portend lower retail profitability but greater savings for consumers.
\end{abstract}

\section{Introduction}

At the end of the twentieth century, the potential of electronic commerce fueled investor optimism and helped propel U.S. equity valuation to historic heights. Investors believed that productivity gains of network technology would generate increased corporate profitability for companies involved in electronic commerce. Although the bubble has burst on Internet valuations, the question remains about whether innovations that lower production costs will result in increased profitability. In a competitive market, lower costs produce lower prices. Innovative firms may be able to capture abnormal profits before other firms in the industry adopt the new technology or business mode but once the innovation is widely diffused, sustained profitability is possible only if significant barriers to entry exist. This paper examines discount retailers, a category that includes firms like Wal-Mart and Kmart, to determine whether increased efficiency attributable to improvements in distribution and inventory management have resulted in abnormal profits for retailers or lower prices for consumers. The fortunes of discount retailers during a period of technological innovation may be a harbinger of the financial impact that electronic commerce will have upon retailers. 


\section{The Internet, Retailers and the Treadmill}

This work is motivated by the uncertainty regarding valuations of Internetbased retailers. In 1998 and 1999, financial analysts were discarding traditional price-earnings $(\mathrm{P} / \mathrm{E})$ valuation models for other methods in order to justify the high valuations of etailers (Laderman \& Smith, 1998). Although many Internet companies lost the majority of their market valuation when the NASDAQ corrected sharply in 2000 , analysts continue to disagree about the proper valuation of companies utilizing a new technology (Trueman, Wong \& Zhang, 2000; Schwartz \& Moon, 2000). One of the arguments advanced for high market valuations of Internet retailers is the increased efficiency and the reduced costs that the Internet brings to businesses (Johnson, 1999; Tully, 2000). However, the benefits of cost saving technology may not accrue to the firm. Instead, consumers may enjoy lower prices or a factor of production, like labor or landowners, may realize increased compensation.

The agricultural economics and resource economics literature documents the equivocal results that technological innovation can have on producers. Cochrane (1958) introduced the concept that farmers are on a product price treadmill. Profits that result from the adoption of new technologies evaporate as increased competition drives price down. Farmers constantly strive to improve their incomes by adopting new technologies. Lower costs ensure that early adopters of the technology enjoy above average profits for at least a brief period of time. However, as more farmers adopt the technology, production increases and prices decrease. The product price treadmill benefits consumers through lower food prices, but farm profitability remains relatively low.

A similar product price treadmill can exist in the retailing industry. Growth in the retail industry is constrained by growth in consumer spending. For a given amount of consumer spending, retailing is a zero sum game. One retailer's gain becomes another retailer's loss. Technological innovation can benefit the initial innovators, but as more firms adopt the technology, prices, and therefore profits, can decline through increased competition.

The Internet has, and will continue to have, a significant impact upon retailing. Retailers use the Internet as an efficient marketing medium, and for digitized products like software, as a distribution channel. However, if a treadmill exists in retailing, the Internet may not benefit the industry through sustained increased profitability. In fact, the Internet, through greater price transparency, may increase the speed of the treadmill by fueling competition (Sinha, 2000). The effect of the Internet upon retail profitability can only be measured with hindsight. Nevertheless, the effect of previous technological innovations on retailers can be measured by studying historical retail profitability. 


\section{Innovation and Profitability}

Retail innovations can take various forms. Walters and Laffey (1996) identify four categories of retail innovations: new delivery systems, new products or services, improvements in existing products, and the development of superior product or service attributes. Process innovations straddle several of these categories: they allow retailers to modify delivery systems, decrease costs and improve the shopping experience for consumers.

The information revolution has generated numerous productivity enhancing processes. Throughout the 1980s and 1990s, retailers have exploited information technology (IT) to decrease costs and improve customer service. Some of these initiatives include synchronized consumer response, quick response, vendor-managed inventories, and demand-chain management solution (Fioritio, May \& Straughn, 1995; Simbari, 1996). Retailers have implemented improvements in the management of goods and services continuously over the past 20 years.

Ultimately, investors would like to see innovation affect the profitability of the firm, which can be measured by the return on equity (ROE). Using the extended Dupont relationship, ROE can be partitioned into contributing components (Selling \& Stickley, 1990):

$$
\begin{aligned}
& \text { ROE }=\text { EBITM * Asset Turnover * }(1-\text { Interest and Tax Load }) \\
& * \text { (Equity Multiplier) }
\end{aligned}
$$

The first two terms are operating outcomes. The second two terms are financial structure outcomes. Earnings before interest and taxes margin (EBITM = EBIT/Sales), also known as operating profit margin, represents the portion of each sales dollar that a firm converts into operating profit. Asset turnover (Sales/Assets) represents the sales dollars produced by one dollar of assets. The interest and tax load depend upon a firm's capital structure and tax management policies. The equity multiplier (assets/equity) measures the firm's financial leverage.

Adopting IT to improve processes affects ROE through operating performance, either due to increased profit margins or increased turnover. First, improved inventory management should decrease inventory levels resulting in lower asset requirements and higher asset turnover. Second, IT can increase worker productivity, leading to lower labor requirements per dollar of sales. A reduction in workforce requirements results in lower payrolls and higher profit margins. Third, IT can result in better stock management leading to less stockouts, less obsolete products, and increased customer satisfaction. Greater product availability can lead to increased customer spending resulting in higher turnover. Stock management can also increase profit margins by decreasing the amount of merchandise that must be sold at clearance. 
Although IT should have a positive impact upon financial ratios, previous research has indicated that improved production techniques may not translate into superior financial performance. Just-In-Time production (JIT) is a case in point. The resources that are freed up by more efficient inventory management need to be utilized for the firm to realize improved profitability (Mia, 2000). Balakrishnan, Linsmeier, and Venkatachalam (1996) studied the cross-sectional results of firms that adopted JIT production compared to a control group that did not adopt JIT. Their results showed that firms which adopted JIT did not, on average, have a significant return on asset (ROA) response to JIT adoption. Mia (2000) found that JIT profitability depends upon the provision of information in a firm's management accounting system. In summary, adopting a process innovation will improve a firm's financial performance only if the innovation is properly implemented.

\section{Discount Retailers and Innovation}

In contrast to the Mia (2000) and Balakrishnan et al. (1996) studies, I do not measure the impact of a specific technology on individual firms, but rather the effect of a series of technological innovations on the entire industry. Discount retailers, formally classified as variety retailers with a SIC number of 5331, provide an ideal segment to study the effects of technological innovation, and hence the potential impact of the Internet, on the retail industry. During this period, the industry has invested aggressively in IT and has had dynamic growth. During the 1990s annual sales growth in the discount retail industry averaged 5.8 percent exceeding the 5.5 percent growth of general retailers (Sack, 2000). The innovativeness of the discount retail industry leader, Wal-Mart, has even had an effect upon other retail channels by forcing firms to adopt new innovations for their survival (Kaufman, 2000).

This study examines operating performance variables to determine whether the industry has had a significant increase in efficiency and profitability from 1981-1998. Inventory turnover, total asset turnover, sales per employee, operating profit margin, basic earning power and cost of goods sold as a percentage of sales are each analyzed for significant changes. Each of the series was tested for stationarity by regressing the variables against time, with the following model:

$$
Y_{t}=\beta_{0}+\beta_{l t}=E_{t}
$$

The null hypothesis of $B_{1}=0$ implies a stationary or trendless series. A significant $B_{1}$ results in a rejection of the null hypothesis. A positive $B_{1}$ indicates an increasing trend; a negative coefficient indicates a decreasing trend.

A priori, the following results are expected for each of the variables: Inventory turnover: Positive trend coefficient. Investment in IT and improved distribution and inventory management procedures should translate into higher inventory turnover. 
Total asset turnover: Positive trend coefficient. A reduction in inventory should result in higher total asset turnover.

Sales per employee: Positive trend coefficient. Increased productivity should result in higher sales per employee.

Operating profit margin. Indeterminate trend coefficient. The change in operating profit margin depends upon the industry structure. In a price-competitive industry, return on investment will trend toward an equilibrium, or normal, level. Competition would ensure that innovations leading to increased total asset turnover would not increase return on investment. An increase in total asset turnover would be accompanied by a decrease in operating margin. In a less competitive industry, operating profit margin could increase as costs decrease in response to improved productivity. Firms capture the gains of cost decreases through higher investment returns. If retailing is competitive, and a product price treadmill exists, operating profit margin would be expected to fall if total asset turnover increased.

Basic earning power: Non-negative trend coefficient. Operating returns should remain constant if retailing is competitive and there are no economywide trends in operating returns. If retailing has barriers to entry or other non-competitive characteristics, productivity improvements can translate into enhanced BEP.

Cost of goods sold as percentage of sales: Non-negative trend coefficient. In a competitive industry, consumers should realize the gains in retail efficiency through decreased retail mark-ups. Cost of goods sold as a percentage of sales should increase. If the industry is not competitive, firms can capture increases in productivity for themselves, in which case, cost of goods sold as percentage of sales would be unchanged.

\section{Data and Results}

Data from 1981-1998 were obtained from Compustat active and research files for firms identified by the SIC code of 5331 (variety stores). Data collected included sales, cost of goods sold, earnings before interest and taxes (EBIT), inventory turnover, total asset turnover, EBIT/total assets, and number of employees. Table 1 summarizes the data.

Statistics for sales, cost of goods sold, and total employees were calculated by summing variables for the entire industry within the sample. Inventory turnover, total asset turnover, operating profit margin, and basic earning power were found by using a sales weighted average. As a quality check, the Compustat data were compared to data from an industry report (Discount Merchandiser, 1997) for consistency.

Inventory turnover, total asset turnover, sales per employee, EBIT margin, basic earning power (EBITM/Assets), and cost of goods sold as a percentage of sales were regressed against time to test for stationarity. Table 2 reports the 
Table 1

Summary Financial Ratios for the Variety Store Industry (SIC 5331)

\begin{tabular}{ccccccccc}
\hline Year & $\begin{array}{c}\text { Number of } \\
\text { Firms }\end{array}$ & $\begin{array}{c}\text { Inventory } \\
\text { Turnover }\end{array}$ & $\begin{array}{c}\text { Total Asset } \\
\text { Turnover }\end{array}$ & $\begin{array}{c}\text { EBIT } \\
\text { Margin }(\%)\end{array}$ & $\begin{array}{c}\text { Basic Earning } \\
\text { Power }(\%)\end{array}$ & $\begin{array}{c}\text { COG/ } \\
\text { Sales }\end{array}$ & $\begin{array}{c}\text { Sales/ } \\
\text { Employee x 1000 }\end{array}$ & $\begin{array}{c}\text { Total Sales } \\
\text { (Millions) }\end{array}$ \\
\hline 1981 & 28 & 4.70 & 2.64 & 4.16 & 11.00 & 0.73 & $\$ 63.12$ & $\$ 36,238$ \\
1982 & 27 & 4.71 & 2.56 & 4.73 & 12.09 & 0.72 & $\$ 71.08$ & $\$ 37,908$ \\
1983 & 27 & 4.91 & 2.60 & 5.98 & 15.55 & 0.72 & $\$ 73.51$ & $\$ 43,230$ \\
1984 & 27 & 4.87 & 2.60 & 5.77 & 14.99 & 0.72 & $\$ 74.24$ & $\$ 47,074$ \\
1985 & 31 & 4.80 & 2.48 & 5.36 & 13.30 & 0.73 & $\$ 68.28$ & $\$ 51,671$ \\
1986 & 32 & 5.11 & 2.58 & 5.39 & 13.88 & 0.73 & $\$ 77.00$ & $\$ 61,578$ \\
1987 & 31 & 5.19 & 2.70 & 4.82 & 12.99 & 0.74 & $\$ 84.23$ & $\$ 70,781$ \\
1988 & 29 & 4.75 & 2.49 & 5.03 & 12.52 & 0.74 & $\$ 82.80$ & $\$ 92,014$ \\
1989 & 29 & 5.39 & 2.78 & 4.71 & 13.09 & 0.75 & $\$ 89.76$ & $\$ 104,990$ \\
1990 & 31 & 5.34 & 2.75 & 4.48 & 12.31 & 0.75 & $\$ 95.08$ & $\$ 118,924$ \\
1991 & 34 & 5.66 & 2.77 & 4.49 & 12.41 & 0.76 & $\$ 109.44$ & $\$ 138,899$ \\
1992 & 36 & 5.20 & 2.48 & 4.48 & 11.11 & 0.78 & $\$ 126.15$ & $\$ 172,417$ \\
1993 & 33 & 5.40 & 2.52 & 4.31 & 10.87 & 0.76 & $\$ 122.74$ & $\$ 173,163$ \\
1994 & 34 & 5.52 & 2.57 & 4.00 & 10.26 & 0.77 & $\$ 116.57$ & $\$ 193,018$ \\
1995 & 32 & 5.36 & 2.54 & 3.24 & 8.23 & 0.78 & $\$ 125.75$ & $\$ 209,693$ \\
1996 & 32 & 5.75 & 2.66 & 3.73 & 9.93 & 0.78 & $\$ 142.34$ & $\$ 225,483$ \\
1997 & 31 & 6.09 & 2.74 & 4.22 & 11.55 & 0.78 & $\$ 145.91$ & $\$ 246,702$ \\
1998 & 25 & 6.45 & 2.79 & 4.58 & 12.80 & 0.78 & $\$ 136.06$ & $\$ 270,902$ \\
\hline
\end{tabular}

Source: Compustat Active and Research Files. Calculations based upon a sales weighted average. 
parameter estimate for the time variable value, its corresponding $t$ statistic, and its significance level.

Table 2

Tests for Stationarity

\begin{tabular}{lccc}
\hline Variable & Parameter Estimate & T Statistic & Probability >0 \\
\hline Inventory Turnover & 0.080 & 7.622 & 0.0001 \\
Total Asset Turnover & 0.006 & 1.166 & 0.2608 \\
Sales Per Employee & 5.029 & 14.421 & 0.0001 \\
EBIT Margin & -0.084 & -3.370 & 0.0039 \\
EBIT Margin/Assets & -0.190 & -2.746 & 0.0144 \\
COG/Sales & 0.004 & 12.610 & 0.0001 \\
\hline
\end{tabular}

Inventory turnover has a positive and significant coefficient indicating that discount retailers managed their inventory more efficiently in the sample period. Turnover of 4.7 times in 1981 corresponds to an inventory period of 77.7 days. Turnover of 6.45 times in 1998 corresponds to an inventory period of 56 days. The inventory period decreased 28 percent from 1981 to 1998 . The parameter estimate of 0.080 indicates that the inventory period decreases by approximately 1.5 days per year.

The increase in inventory turnover does not seem to have translated into an increase in asset turnover. The total asset turnover coefficient was positive but insignificant. The result is surprising, although consistent with the findings of Balakrishnan et al. (1996) and Mia (2000), since inventory constitutes approximately one third of assets for variety retailers. A significant decrease in inventory requirements should correspond to a decrease in total asset requirements. Further study is needed to determine which asset categories increased to offset the decrease in inventory.

Increased productivity is evident through the considerable increase in sales per employee. The positive and significant regression coefficient for sales per employee indicates that discount retailers increased labor productivity during the 1981-1998 sample period. The regression coefficient of 5.029 implies that sales per employee increased approximately $\$ 5,000$ per year. Salaries constitute a significant portion of retail operating expense. Increases in labor productivity decrease a firm's labor requirements and reduce salary expense.

Both EBIT margin and BEP have negative and significant regression coefficients, indicating that profitability for discount retailers deteriorated during the sample period. However, both ratios reversed their steady decline with increases from 1996 through 1998. Perhaps competitive pressures in the industry have abated or perhaps the industry has begun to move to higher margin merchandise.

Increased efficiency in the variety retail industry has translated into gains for consumers. The regression parameter for $\mathrm{COG} / \mathrm{Sales}$ was positive and signifi- 
cant, indicating that consumers paid a smaller markup over the time period. The increase of 5 percent from 1981 to 1998 may seem relatively small but it represents significant savings for consumers. The variety retail industry had total sales of $\$ 256.3$ billion in 1998 , representing a cost of goods sold of $\$ 199.9$ billion. If the mark-up of 1981 were applied to the 1998 cost of goods sold figures, consumer expenditures would have been $\$ 273.9$ billion in 1998 . Without considering the impact that the discount retailers have had on other retailers, consumers saved approximately $\$ 17.6$ billion in 1998 due to increased discount retail efficiency. Although increased productivity does not seem to have translated into increased profitability for industry, consumers have benefited through lower prices. Other potential benefits for consumers, including convenience, merchandise availability, and merchandise selection are not measured in this study.

\section{Implications for Retailers and Electronic Commerce}

Discount retailers experienced a tremendous increase in efficiency in the 1981-1998 period. Inventory turnover increased 37 percent and sales per employee increased 115 percent. Unfortunately for the retailers, these gains did not translate into higher operating profits. Operating profit margins remained trendless; margins fluctuated between four and five percent during the period. Likewise, basic earning power was relatively flat, fluctuating between 11 percent and 15.5 percent. Productivity gains translated into lower prices for consumers. Cost of goods sold as a percentage of price increased steadily throughout the period.

The effects of the Internet upon retailing may be similar to the process efficiencies realized by discount retailers; customers may benefit but at the expense of firm profitability. The Internet increases price transparency, which results in more competition. As Sinha (2000) states, "the Internet represents the biggest threat thus far to a company's ability to brand its products, extract price premiums from buyers, and generate high profit margins."

The extent to which the Internet benefits firms or consumers depends upon the nature of the product and the existing market structure of the industry. Efficiencies will be generated in product categories in which the Internet can increase inventory turnover and reduce product management expense. The cost-saving benefits of the Internet will accrue largely to consumers unless a non-competitive market structure or substantial barrier to entry exists.

\section{Conclusion}

The discount retail industry achieved significant increases in productivity from 1981-1998. The productivity increases did not improve industry profitability. Instead, consumers benefited through lower markups. Like agriculture, the 
retail industry may be on a product price treadmill. Productivity gains due to innovation lead to lower costs and lower prices, but profitability remains unchanged. Innovations raise the standards that firms must meet. Firms either adopt the new technology or are forced out of the market. The Internet has the potential to increase retail efficiency but firms can capture the gains only if the market lacks price competition.

Although this study examined overall productivity changes in the discount retail industry, other factors besides technological innovation can be responsible for changes in costs and profitability. In this study, innovations due to IT are commingled with other effects, such as changes in consumer demand and changes in product and input costs. Future studies may seek to measure the efficiency changes due to the implementation of specific technologies. Such studies would need firm-specific data, including capital expenditures on IT.

\section{References}

Balakrishnan, R., Linsmeier, T. J. \& Venkatachalam, M. (1996). Financial benefits from JIT adoption. The Accounting Review, 71, 183-205.

Cochrane, W. W. (1958). Farm prices: Myth and reality. St. Paul: University of Minnesota Press.

Demsetz. H. (1973). Industry structure, market rivalry, and public policy. Journal of Law and Economics, XVI (1), 1-9.

Discount Merchandiser (1997). The true look: 1997 state of the industry report. 37 (6), 29-54.

Fioritio, S., May, E. G. \& Straughn, K. (1995). Quick response in retailing: Components and implementation. International Journal of Retail and Distribution Management. $23(5), 12-21$.

Hayashi, A. M. (1997). Squeezing profits from IT. Datamation, 43 (7), $42-47$.

Heard, E. (1994). Quick response: Technology or knowledge? Industrial Engineering. $\underline{26}(8), 28-30$.

Johnson, J. (1999), Bubble.com or valuing an Internet company, Management Today, August, 60-63.

Kaufman, L. (2000, October 22). As biggest business, Walmart propels changes elsewhere. New York Times, 1.

Laderman, J. M. \& Smith, G. (1998). Internet stocks: What's their real worth? Business Week, $12(14), 120-124$. 
Mia, L. (2000). Just-in-time manufacturing, management accounting systems and profitability. Accounting and Business Research. 30 (2), 137-151.

Sack, K. J. (2000). Retailing: General. Standard \& Poor's Industry Surveys, 168 (21), 1 30.

Schwartz, E. S. \& Moon, M. (2000). Rational pricing of internet companies. Financial Analysts Journal, 56 (3), 62-75.

Selling T. L. \& Stickney, C. P. (1980). Disaggregating the rate of return on common shareholders' equity: A new approach." Accounting Horizons, 4 (4), 9-17.

Simbari, D. J. (1996). Competitive advantages. Manufacturing Systems, 14 (9), 92-96.

Sinha, I. (2000). Cost transparency: The net's real threat to prices and brands. Harvard Business Review, 78 (2), 43-49.

Trueman, B., Wong, F. M. H. \& Zhang, Z. J. (2000). The eyeballs have it: Searching for the value in Internet stocks. Working Paper, Haas School of Business, University of California Berkeley.

Tully, S. (2000). Has the market gone mad? Fortune, 141 (2), 80-84.

Walters, D. \& Laffy, D. (1996). Managing retail productivity and profitability, London: Macmillan Press, Ltd.

Richard Skolnik (Ph.D., Rensselaer Polytechnic Institute) is an Assistant Professor of Finance at the State University of New York at Oswego. A Chartered Financial Analyst, his current research examines the impact that operational factors have upon profitability. Before academe, he worked for AT\&T as a market analyst in the international telecommunication group. In addition to a Ph.D. in Managerial Economics, he has a M.S. in Operations Research and Statistics. 